\title{
Short communication: Prevalence and risk factors of subclinical mastitis as determined by the California Mastitis Test in water buffaloes (Bubalis bubalis) in Nueva Ecija, Philippines
}

\author{
R. T. Salvador, ${ }^{* 1}$ J. M. C. Beltran, ${ }^{* 1}$ N. S. Abes,, C. A. Gutierrez, $\dagger$ and C. N. Mingala $\dagger^{2}$ \\ ${ }^{*}$ College of Veterinary Science and Medicine, Central Luzon State University, Science City of Munoz, Nueva Ecija, Philippines \\ †Philippine Carabao Center National Headquarters and Gene Pool, Science City of Munoz, Nueva Ecija, Philippines
}

\begin{abstract}
A retrospective analysis using records of lactating Bulgarian Murrah buffaloes subjected to the California Mastitis Test in a herd in Nueva Ecija, Philippines was done to determine the prevalence of subclinical mastitis (SCM) and to identify risk factors that may influence its occurrence and recurrence. Results showed that SCM prevalence was $42.76 \%$, whereas its recurrence was $75.03 \%$. Age and lactation length influenced the occurrence of SCM. In contrast to the conclusions for dairy cows, younger buffalo cows were more susceptible compared with those at least 6 yr old. Dams younger than 3 yr have a $76 \%$ probability, whereas those age 3 yr have an $82 \%$ probability of having SCM.
\end{abstract}

Key words: water buffalo, subclinical mastitis, Philippines

\section{Short Communication}

Mastitis is a significant infectious disease among lactating cows. It decreases the quantity and quality of milk produced, resulting to heavy economic losses. The US dairy industry is losing approximately $\$ 2$ billion annually. A similar impact is observed in Europe and other countries (Donovan et al., 2005; Denis et al., 2009). The condition is also associated to public health risks brought about by contaminated raw milk and antibiotic residues as a consequence of drug therapy (Andrew et al., 2009).

Subclinical mastitis (SCM), the asymptomatic inflammation of mammary tissue, is the most common form of mastitis. It is 15 to 40 times more common than clinical cases (Horner and Randles, 1995; Khan and Muhammad, 2005; Sori et al., 2005; Roy et al., 2009; Mekibib et al., 2010). Applying the iceberg concept of infection (Gay, 2009), SCM is a bigger concern than

\footnotetext{
Received May 2, 2011.

Accepted November 11, 2011.

${ }^{1}$ Both authors contributed equally to this work.

${ }^{2}$ Corresponding author: cnmingala@hotmail.com
}

clinical mastitis. Several consequences are involved when a cow is suffering from SCM. Because it remains undetected without the use of SCC, a measure not available to regular raisers of dairy animals, no intervention management is implemented. Similarly, the incurred production losses will not be addressed. Moreover, cows with SCM have a 3.32 incidence risk ratio (Compton et al., 2007) for clinical mastitis. Hence, it is imperative to identify risk factors that can be used as basis for potential control programs.

Mastitis prevalence was found to be significantly influenced by stage of lactation, parity, breed, milk yield, BW, anatomical abnormality of the udder, and some management aspects including nutrition (Almaw et al., 2008). However, virtually all of the published information about the risk factors for mastitis refers to dairy breeds of cattle, and little information available for water buffaloes. Though a high probability exists that these identified risk factors may also be observed among these species, the degree of influence by these factors is still unknown.

Generally, the current study determined the prevalence of SCM of water buffaloes at the Philippine Carabao Center Gene Pool. The risk factors associated with its occurrence, recurrence, and prolonged duration were identified and quantified.

A retrospective analysis using records of lactating water buffaloes subjected to the California Mastitis Test (CMT) at the Philippine Carabao Center Gene Pool from September 2006 to June 2009 was done. Antibiotic therapy for the herd during this period is not yet practiced by the gene pool.

The records were cleaned to avoid duplication of entries. Once an animal is classified as a case, succeeding results of the CMT test for the same animal were no longer entered in the data. However, another data file containing all results of the series of CMT done was maintained for statistical analyses of SCM recurrence in the herd.

A case of SCM was defined as the presentation of $\geq 1$ positive CMT in at least 1 quarter of the udder. 
Table 1. Prevalence of subclinical mastitis across the different variables

\begin{tabular}{lccc}
\hline Variable & $\mathrm{n}$ & Cases & Prevalence \\
\hline Age (yr) & & & \\
$<3$ & 48 & 22 & 45.83 \\
$\geq 3$ & 64 & 38 & 59.38 \\
$\geq 4$ & 60 & 25 & 41.67 \\
$\geq 6$ & 33 & 10 & 30.30 \\
Lactation length (d) & & & \\
15 to 30 & 53 & 50 & 48.54 \\
$\geq 31$ & 54 & 28 & 35.85 \\
$\geq 61$ & 48 & 17 & 53.66 \\
Parity & 123 & 66 & 34.38 \\
1 & 32 & 11 & 33.33 \\
2 & 45 & 15 & 44.05 \\
$\geq 3$ & & & 46.39 \\
Calf sex & 84 & 37 & 45.45 \\
Female & 97 & 45 & 44.23 \\
Male & & & 43.48 \\
Calving months & 33 & 15 & 53.33 \\
Jpril, May, June August, September & 52 & 23 & \\
October, November, December & 46 & 20 & 24 \\
January, February, March & 45 & & \\
\hline
\end{tabular}

To address false-positive results due to the influence of colostrum that is secreted during the first week of lactation (Czerniawska-Piątkowska et al., 2010), CMT results for the first 2 wk of lactation were disregarded. The results of the succeeding CMT were adopted. Recurrent cases were those cases observed to reappear within 1 lactation cycle after a case tested negative in the CMT during the preceding test schedule. This paper defined prolonged infection as those lasting more than a month. True prevalence was calculated with the sensitivity $(82.4 \%)$ and specificity $(80.6 \%)$ of the CMT being considered.

For the potential risk factors associated with the occurrence of SCM, covariates considered include the parity number, age, length of lactation, month of calving, and sex of the calves. Variables considered in the analyses for the risk factors associated with SCM recurrence include parity number, age, length of lactation, month of calving, sex of the calves, duration of first infection, and the number of teats affected in their first episode of SCM. The variables analyzed for prolonged SCM infection included parity number, age, stage of lactation, month of calving, and the number of teats affected.

Parity number was defined as the number of times cows have given birth. Parities were classified according to the number of calvings a cow had. Other than the first and the second parity, parities greater than or equal to 3 were grouped to form a single category (Table 1). Parities 2 and 3 were further collapsed in modeling the influence of this variable on the recurrence of SCM and its prolonged duration due to the decrease in frequency distribution.
Age was also considered. This is due to the observation that cows are not necessarily young during their first parity. This was derived by taking the difference between the dates of milk collection for the CMT and the birth date of the cow. The result was subsequently divided by $365 \mathrm{~d}$ to express this variable as years. Categories were based on quartile distribution (Table 1). Categories 3 and 4 ( $\geq 4$ and $\geq 6$ yr) were further collapsed into a single category for the analysis of age as a factor in the recurrence SCM and its prolonged duration.

Length of lactation was the difference between the date of the CMT and the closest calving date. This variable was expressed in months, with month defined as 30 d. Three categories were formed (Table 1). Categories 2 and 3 were further collapsed into a single category to quantify the effect of this variable on the recurrence of SCM and its prolonged duration.

Moreover, month of calving was arbitrarily grouped with 3 mo included in each category (Table 1). The categories were subsequently collapsed into just 2 groups with 6 mo each (April to September and October to March).

The duration of first infection was also considered as a potential factor in the recurrence of SCM. This variable was derived by taking the difference between the date when an animal was diagnosed as SCM positive and the date when the succeeding test that yielded a negative CMT result. Two categories were derived based on the distribution of recurrent cases $(\leq 60$ and $\geq 61 \mathrm{~d}$ ).

The data were analyzed using logistic regression analysis with models being constructed using backward 
elimination. The level of significance was set at $10 \%$. All statistical analysis was done using SAS software, (SAS Institute Inc., Cary, NC).

The true prevalence of SCM was 42.76 (95\% CI: $38.57-46.95)$, whereas its recurrence was $75.03 \%$ (95\% CI: $69.15-80.90)$. The frequency of recurrence ranged from 2 to 7 (mean =3.36). The duration of SCM infection, on the other hand, ranged from 9 to $322 \mathrm{~d}$ (mean $=80.46 \mathrm{~d}$; mode $=35 \mathrm{~d}$ ). The high prevalence of SCM can be attributed to the non-adoption of therapeutic management during the period covered. Prior bacterial cultures for infected milk resulted to the isolation of Staphylococcus species, Streptococcus species, Corynebacterium species, and Escherichia coli.

Only age and lactation length influence the occurrence of SCM among cows (Table 2). Younger cows were more susceptible compared with those at least 6 yr old. Cows younger than 3 yr had a $76 \%$ probability [odds ratio $(\mathbf{O R})=3 ; P=0.06$, whereas those $3 \mathrm{yr}$ of age have an $82 \%$ probability $(\mathrm{OR}=4.63 ; P=0.009)$ to have SCM. The risk among 4-yr-old dams is comparable to those at least $6 \mathrm{yr}$ old. Likewise, a higher risk exists among cows to have SCM during their first 2 mo of lactation. Those lactating 15 to $30 \mathrm{~d}$, and 31 to $60 \mathrm{~d}$ postcalving are 2.45 times ( $71 \%$ probability; $P=0.03$ ) and 2.14 times $(68 \%$ probability; $P=0.08)$ more likely to have SCM, respectively.

The results are in direct contrast with earlier studies for dairy cows. Mungube et al. (2004) showed that cows aged at least $8 \mathrm{yr}$ and in at least the eighth month of lactation had a significantly higher risk for SCM. Likewise, Olde Riekerink et al. (2007) concluded that older and late-lactation cows were more likely to develop or maintain a high individual cow somatic cell count. This is the same scenario described by Ali (2009) and Petrovski et al. (2009). The linear relationship of advancing age and mastitis prevalence was linked to the gradual suppression of the immune system of the body and structural changes in the udder and teats.

Table 2. Odds ratio estimates of factors significantly associated to the occurrence of subclinical mastitis

\begin{tabular}{lll}
\hline Variable & $\begin{array}{l}\text { Odds } \\
\text { ratio }\end{array}$ & $P$-value \\
\hline Age (yr) & & \\
$<3$ & 3.175 & 0.0633 \\
$\geq 3$ & 4.635 & 0.0096 \\
$\geq 4$ & 2.241 & 0.1881 \\
$\geq 6$ & 1 & \\
Lactation length (d) & & \\
15 to 30 & 2.457 & 0.0388 \\
$\geq 31$ & 2.140 & 0.0868 \\
$\geq 61$ & 1 & \\
\hline
\end{tabular}

However, the finding of Petrovski et al. (2009) and Dhakal et al. (2007) relative to the stage of lactation is in agreement with the result of the current study. This result is also in agreement with the findings of Lakshmi Kavitha et al. (2009). Buffaloes in the first stage of lactation (1-4 mo) and the last part of the dry period (10-12) were more prone to mastitis. The high prevalence of SCM during the first 2 mo of lactation may be related to the stress brought about by the changes in the endocrine, nutritional, and metabolic status of the animal which occur in the periparturient period. The stress related to the adjustment to the milking machine may possibly contribute to this result. The result may also be an indication of infection probably before freshening.

The non-agreement of the findings of this paper with other papers on the relationship of age and mastitis occurrence may be related to several factors. Most of the previous studies for dairy cows used SCC, a more sensitive measure for mastitis. The argument with the case definition set where a cow with at least 1 CMT-positive teat classified as a case is the possibility that those with only 1 affected teat may not meet the required SCC to be classified as an SCM case. However, research related to the SCC cut-off for bubaline mastitis is still in progress and, hence, basis for such a possibility is currently unavailable. Nonetheless, the results of Dhakal (2006) showed that the mean SCC of CMT-positive quarters was significantly higher $(P<0.01)$ than that of CMT-negative quarters. Besides, this paper addressed the possibility of false positives by disregarding CMT results for the first 2 wk of lactation.

Another difference is the statistical approach used. The study of Ali (2009) used linear regression analysis instead of logistic regression analysis. The latter is a better approach to treat categorical variables. Hence, the results of Ali (2009) relative to the relationship of age and mastitis are plainly descriptive with neither OR nor relative risks presented.

Nonetheless, the contrasting results of this paper with the research outputs for dairy cows may be related to the suitability of the milking machines designed for dairy cows. This may indicate the need for further adjustments to the machine pressures or other machinerelated factors that may contribute to the occurrence of teat injuries. Several papers concluded that milking machines can affect udder health (Brandsma, 1981; Noorlander et al., 1981; Grindal and Hillerton, 1991; Miltenburg et al., 1997). The differences in the intrinsic characteristics between the 2 species may also be a factor in producing the contrasting results. No risk factors were found to be significantly associated with the recurrence and prolonged duration of SCM infection. 
Though the conclusions derived from this study are based only on a single herd, it demonstrated that the results for dairy cows relative to the occurrence of mastitis may not be used as an absolute guide in preventing and managing the disease. Management wise, it is easier to address mastitis among cattle. Older cows being more susceptible can be culled. Such an approach is inapplicable to the case of dairy buffaloes. Hence, it is a challenge to establish pragmatic management approaches.

In conclusion, the true prevalence of SCM was 42.76 (95\% CI: 38.57-46.95), whereas its recurrence was $75.03 \%$ (95\% CI: $69.15-80.90)$. The frequency of recurrence ranged from 2 to 7 (mean $=3.36)$. The duration of SCM infection, on the other hand, ranged from 9 to $322 \mathrm{~d}$ (mean $=80.46 \mathrm{~d}$; mode $=35 \mathrm{~d})$. Among the potential risk factors considered for SCM occurrence, only age and lactation length influenced the susceptibility of cows to SCM. Younger cows were more susceptible compared with those at least $6 \mathrm{yr}$ old. Dams younger than 3 yr of age had a $76 \%$ probability $(\mathrm{OR}=3 ; P$ $=0.06)$, whereas those aged $3 \mathrm{yr}$ had an $82 \%$ probability $(\mathrm{OR}=4.63 ; P=0.009)$ of having SCM. Cows were more at risk for SCM during their first 2 mo of lactation postcalving. No risk factors were significantly related to the recurrence of SCM in the herd.

\section{ACKNOWLEDGEMENTS}

We thank Libertado C. Cruz, Executive Director of the Philippine Carabao Center (Nueva Ecija, Philippines), for his valuable support. We also thank Marvin A. Villanueva (Philippine Carabao Center) for his technical assistance.

\section{REFERENCES}

Ali, L. 2009. Epidemiology of mastitis in dairy buffalo and cow in Tehsil Samundri of District Faisalabad. PhD Dissertation. University of Agriculture, Faisalabad, Pakistan.

Almaw, G., A. Zerihun, and Y. Asfaw. 2008. Bovine mastitis and its association with selected risk factors in smallholder dairy farms in and around Bahir Dar, Ethiopia. Trop. Anim. Health Prod. 40:427-432.

Andrew, S. M., K. M. Moyes, A. A. Borm, L. K. Fox, K. E. Leslie, J. S. Hogan, S. P. Oliver, Y. H. Schukken, W. E. Owens, and C. Norman. 2009. Factors associated with the risk of antibiotic residues and intramammary pathogen presence in milk from heifers administered prepartum intramammary antibiotic therapy. Vet. Microbiol. 134:150-156.
Brandsma, S. 1981. The milking machine as a factor in udder health Tijdschr. Diergeneeskd. 106:508-514. (Dutch).

Compton, C. W., C. Heuer, K. Parker, and S. McDougall. 2007. Risk factors for peripartum mastitis in pasture-grazed dairy heifers. J. Dairy Sci. 90:4171-4180.

Czerniawska-Piątkowska, E., E. Chociłowicz, and M. Szewczuk. 2010. Biology of Bubalus bubalis. Ann. Anim. Sci. 10:107-115.

Denis, M., D. N. Wedlock, S. J. Lacy-Hulbert, J. E. Hillerton, and B. M. Buddle. 2009. Vaccines against bovine mastitis in the New Zealand context: What is the best way forward? N. Z. Vet. J. 57:132-140.

Dhakal, I. P. 2006. Normal somatic cell count and subclinical mastitis in Murrah buffaloes. J. Vet. Med. B Infect. Dis. Vet. Public Health 53:81-86.

Dhakal, I. P., P. Dhakal, T. Koshihara, and H. Nagahata. 2007. Epidemiological and bacteriological survey of buffalo mastitis in Nepal. J. Vet. Med. Sci. 69:1241-1245.

Donovan, D. M., D. E. Kerr, and R. J. Wall. 2005. Engineering disease resistant cattle. Transgenic Res. 14:563-567.

Gay, J. 2009. Epidemiology concepts for disease in animal groups. College of Veterinary Medicine. Washington State University Accessed Aug. 10, 2010. http://www.vetmed.wsu.edu/coursesjmgay/EpiMod2.htm.

Grindal, R. J., and J. E. Hillerton. 1991. Influence of milk flow rate on new intramammary infection in dairy cows. J. Dairy Res. $58: 263-268$

Horner, R. F., and J. L. Randles. 1995. Mastitis. Allerton Veterinary Laboratory. Accessed Dec. 5, 2010. http://agriculture.kzntl gov.za/publications/production_guidelines/dairying_in_natal/ dairy8_1.htm.

Khan, A. Z., and G. Muhammad. 2005. Quarter-wise comparative prevalence of mastitis in buffaloes and crossbred cows. Pak. Vet. J. 25:9-12.

Lakshmi Kavitha, K., K. Rajesh, K. Suresh, K. Satheesh, and N. Syama Sundar. 2009. Buffalo mastitis-Risk factors. Buffalo Bull. $28: 134-137$.

Mekibib, B., M. Furgasa, F. Abunna, B. Megersa, and A. Regassa. 2010. Bovine mastitis: Prevalence, risk factors and major pathogens in dairy farms of Holeta Town, Central Ethiopia. Vet. World 3:397-403.

Miltenburg, J. D., C. J. de Koning, J. H. van Vliet, and T. J. Lam. 1997. Machine milking and udder health: A literature review. Tijdschr. Diergeneeskd. 122:568-576. (Dutch).

Mungube, E. O., B.-A. Tenhagen, T. Kassa, F. Regassa, M. N. Kyule, M. Greiner, and M. P. Baumann. 2004. Risk factors for dairy cow mastitis in the central highlands of Ethiopia. Trop. Anim. Health Prod. 36:463-472.

Noorlander, D. O., R. A. Heckmann, and M. Checketts. 1981. Milk gases, mastitis and milking machines. Mod. Vet. Pract. 62:590 594.

Olde Riekerink, R. G. M., H. W. Barkema, and H. Stryhn. 2007. The effect of season on somatic cell count and the incidence of clinical mastitis. J. Dairy Sci. 90:1704-1715.

Petrovski, K. R., C. Heuer, T. J. Parkinson, and N. B. Williamson. 2009. The incidence and aetiology of clinical bovine mastitis on 14 farms in Northland, New Zealand. N. Z. Vet. J. 57:109-115.

Roy, S., P. Vishwakarma, M. Roy, and M. Sharma. 2009. Prevalence and control of bubaline mastitis in Chhattisgarh State in India. Pak. J. Zool. Supplementary Series 9:281-287.

Sori, H., A. Zerihun, and S. Abdicho. 2005. Dairy cattle mastitis in and around Sebeta, Ethiopia. Int. J. Appl. Res. Vet. Med. 3:332-338. 